\title{
Change laws of PHC contents in bottom waters in the bay mouth of Jiaozhou Bay
}

\author{
Dongfang Yang ${ }^{1,2,3, a}$, Sixi Zhu ${ }^{1,2}$, Fengyou Wang ${ }^{1,2, b, c}$, Ming Wang ${ }^{1,2}$ and \\ Xiuqin Yang ${ }^{1,2}$ \\ ${ }^{1}$ Research Center for Karst Wetland Ecology, Guizhou Minzu University, Guizhou Guiyang, \\ Guizhou Guiyang, China; \\ ${ }^{2}$ College of Chemistry and Environmental Science, Guizhou Minzu University, Shanghai, 550025, \\ China; \\ ${ }^{3}$ North China Sea Environmental Monitoring Center, SOA, Qingdao 266033, China. \\ adfyang_dfyang@126.com; ${ }^{b}$ Corresponding author; 'wangfy2001@yahoo.com.cn
}

Keywords: PHC; Distribution; Bottom water; High sedimentation rate; Jiaozhou Bay

\begin{abstract}
Based on investigation data on petroleum hydrocarbon (PHC) in June, July, September and October 1980 in bottom waters in Jiaozhou Bay, we analyzed the content and distribution of PHC. Results showed that PHC contents in June, July, September and October 1980 in bottom waters were $0.028-0.147 \mathrm{mg} \mathrm{L}^{-1}$ and were meeting Grade II $\left(0.05 \mathrm{mg} \mathrm{L}^{-1}\right)$ and III $\left(0.30 \mathrm{mg} \mathrm{L}^{-1}\right)$ in National Sea Water Quality Standard (GB 3097-1997). PHC contents were decreasing from the inside of the bay mouth to the bay mouth, and to the outside of the bay mouth in June, and were decreasing from the inside of the bay mouth to the open waters in September and October, yet were decreasing from the open waters to the inside of the bay mouth in July. We found that no matter from the bay to the open water of from the open water to the bay, the contents of the substances were decreasing continuously by means of vertical water's effect.
\end{abstract}

\section{Introduction}

PHC has been widely used in industry and agriculture, and the PHC-containing waste water has caused the degrading of water quality in marine environment [1-5], and was harmful to human being finally. This paper analyzed the content and distribution of PHC in bottom waters in the bay mouth of Jiaozhou Bay based on investigation data on petroleum hydrocarbon (PHC) in June, July, September and October 1980, and revealed the change laws of PHC in waters, and provide scientific basis for the research on the existence and migration of PHC in marine bay.

\section{Material and method}

Jiaozhou Bay $\left(35^{\circ} 55^{\prime}-36^{\circ} 18^{\prime} \mathrm{N}, 120^{\circ} 04^{\prime}-120^{\circ} 23^{\prime} \mathrm{E}\right)$ is a semi-closed bay located in the south of Shandong Province, eastern China (Fig. 1). The total area and bay mouth depth $446 \mathrm{~km}^{2}$ and $3 \mathrm{~km}$, respectively. The bay has more than ten inflow rivers, including Haibo Rriver, Licun Rriver and Loushan Rriver etc., all of which have seasonal features [6-7]. The data was provided by North China Sea Environmental Monitoring Center. The survey was conducted in June, July, September and October 1980 (Fig. 1). PHC in bottom waters was sampled and monitored follow by National Specification for Marine Monitoring [8].

\section{Results and discussion}

Contents and pollution levels of PHC. The contents of PHC in April, August and November in bottom waters in Jiaozhou Bay were $0.036-0.147 \mathrm{mg} \mathrm{L}^{-1}, 0.033-0.060 \mathrm{mg} \mathrm{L}^{-1}, 0.068-0.102 \mathrm{mg}$ $\mathrm{L}^{-1}$ and 0.028-0.065 $\mathrm{mg} \mathrm{L}^{-1}$, respectively (Table 1). In July, PHC contents in Site H82 in the outside of the bay mouth were lower than $0.05 \mathrm{mg} \mathrm{L}^{-1}$, and were belong to Grade II, while for the other sampling sites, PHC contents were Grade III. PHC contents in July were lower than in June, PHC 
contents in Site H35, H36 and H37 in the inside of the bay mouth were lower than $0.05 \mathrm{mg} \mathrm{L}^{-1}$, and were belong to GradeII, while for the other sampling sites, PHC contents were Grade III. PHC contents in September were higher than in July, PHC contents in all of the sampling sites were high than $0.05 \mathrm{mg} \mathrm{L}^{-1}$, and were belong to III. In October, PHC contents in Site H36 in the bay mouth were higher than $0.05 \mathrm{mg} \mathrm{L}^{-1}$, and were belong to Grade III, while for the other sampling sites were Grade III.

Once PHC was transported to the bay, PHC was originally arrived at the surface waters, and then was transported through the waters, and finally was settled in the sea bottom. By means of the vertical water's effect, PHC contents in Jiaozhou Bay were $0.028-0.147 \mathrm{mg} \mathrm{L}^{-1}$, and were belong to Grand II and III. In generally, Jiaozhou Bay waters were slightly polluted by PHC in 1980.

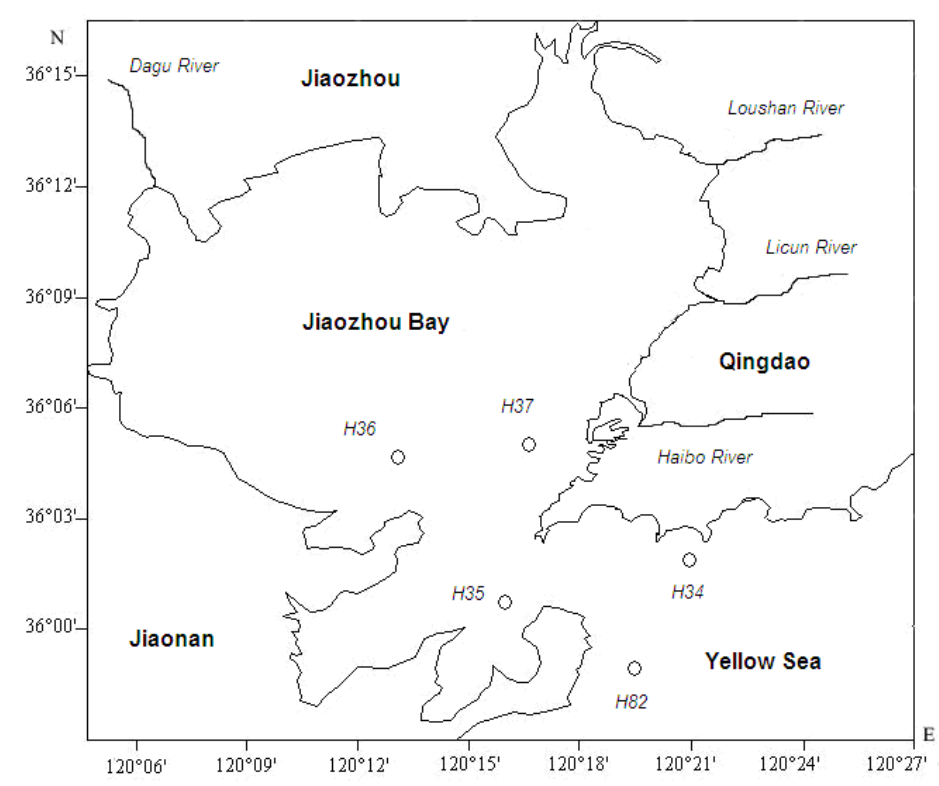

Fig.1 Sampling sites of PHC in Jiaozhou Bay

Table1 Pollution level of PHC in bottom waters in Jiaozhou Bay in April, August and November 1981

\begin{tabular}{|c|c|c|c|c|}
\hline Month & Jule & July & September & Octomber \\
\hline Content/mg L $\mathrm{L}^{-1}$ & $0.036-0.147$ & $0.033-0.060$ & $0.068-0.102$ & $0.028-0.065$ \\
\hline Water quality grade & II and III & II and III & II and III & II and III \\
\hline
\end{tabular}

Horizontal distributions and migration rules of PHC. In June, there was a high value $(0.147$ $\mathrm{mg} \mathrm{L}^{-1}$ ) in Site H35 in the bay mouth, and there were a series of parallel lines, which were decreasing from the high value center to the outside of the bay mouth $\left(0.036 \mathrm{mg} \mathrm{L}^{-1}\right)$ (Fig. 2). In July there was a high value $\left(0.060 \mathrm{mg} \mathrm{L}^{-1}\right)$ in Site H34 in the eastern of the outside of the bay mouth, and there were a series of parallel lines open waters, which were decreasing from the high value center to the outside of the bay mouth $\left(0.028 \mathrm{mg} \mathrm{L}^{-1}\right)$ (Fig. 3). In September, there was a high value $\left(0.102 \mathrm{mg} \mathrm{L}^{-1}\right)$ in Site H36 in the inside of the bay mouth, and there were a series of parallel lines, which were decreasing from the high value center to the outside of the bay mouth $\left(0.068 \mathrm{mg} \mathrm{L}^{-1}\right)$ (Fig. 4). In October, there was a high value $\left(0.065 \mathrm{mg} \mathrm{L}^{-1}\right)$ in Site H36 in the inside of the bay mouth, and there were a series of parallel lines, which were decreasing from the high value center to the outside of the bay mouth $\left(0.028 \mathrm{mg} \mathrm{L}^{-1}\right)$ (Fig. 5). In generally, PHC contents were decreasing from the inside of the bay mouth to the outside, or reverse, with a serious of parallel lines.

The contents of the substances were decreasing continuously from the inside of the bay to the open waters along with the water exchange of the bay and the open waters, and were also decreasing continuously from the open waters to the inside bay [10]. In according to the distributions of PHC contents in June, September and October, we found that PHC were decreasing from the inside of the bay mouth, to the bay mouth, and to the outside of the bay mouth. However, in July, PHC were decreasing from the outside of the bay mouth to the bay mouth, and to the inside of the bay mouth. We hold that, by means of vertical water's effect, the contents of the substances 
could be decreasing continuously from the open waters to the bay, as well as from the bay to the open waters.

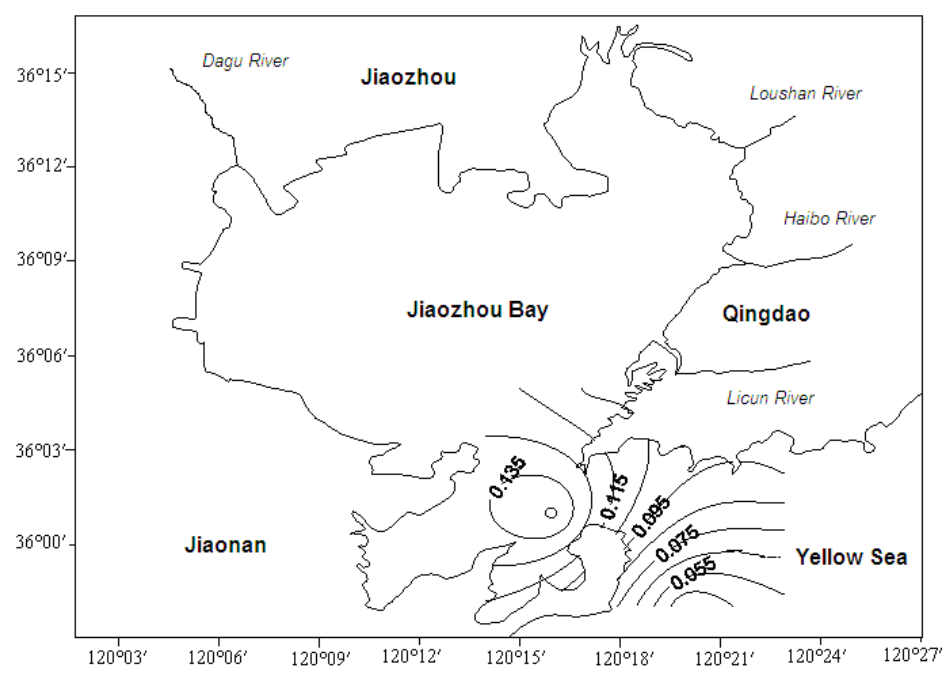

Fig. 2 Horizontal distributions of PHC in bottom waters of Jiaozhou Bay in June 1980

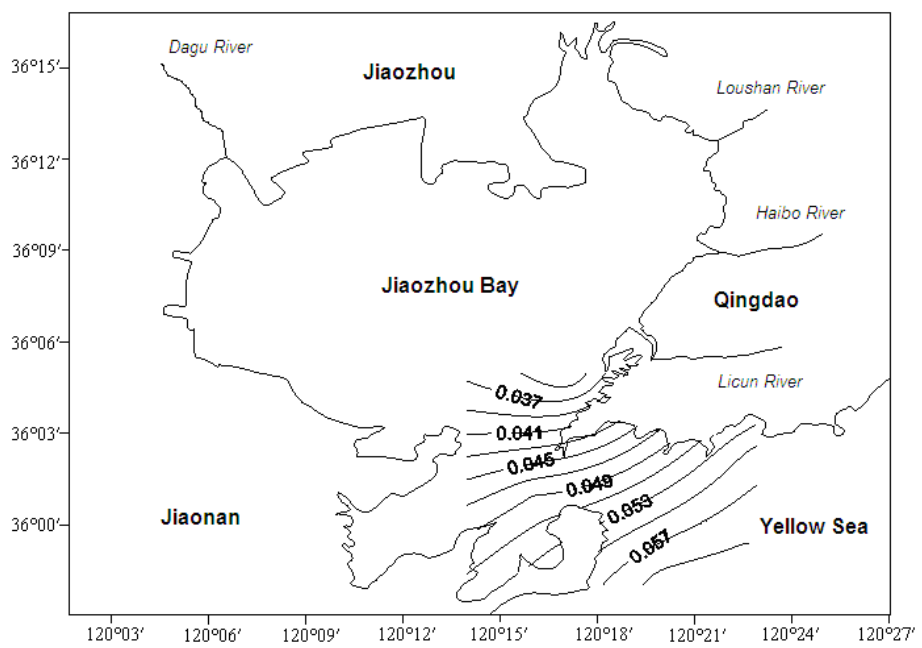

Fig. 3 Horizontal distributions of PHC in bottom waters of Jiaozhou Bay in July 1980

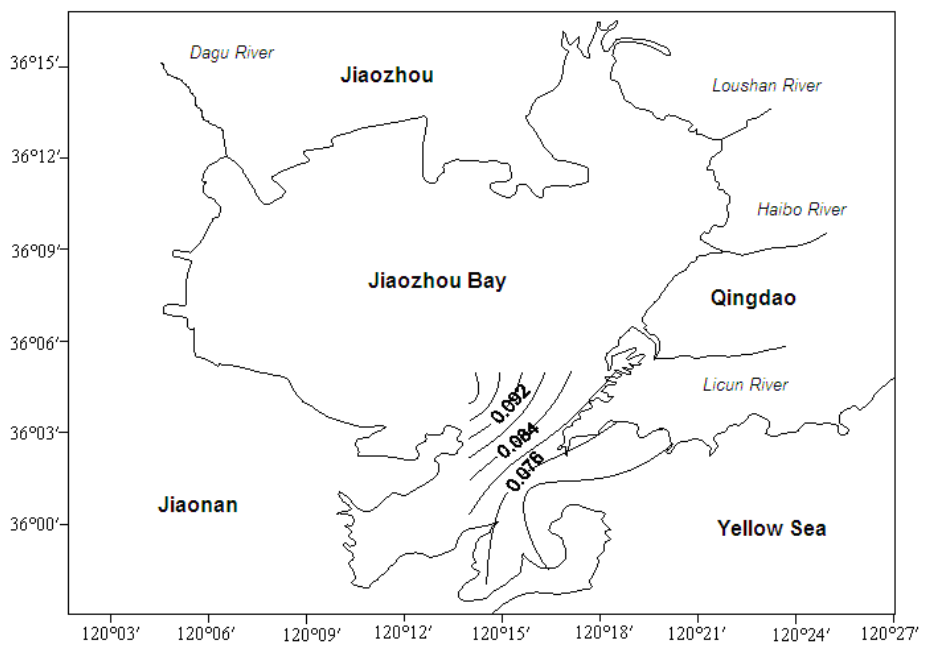

Fig. 4 Horizontal distributions of PHC in bottom waters of Jiaozhou Bay in September 1980 


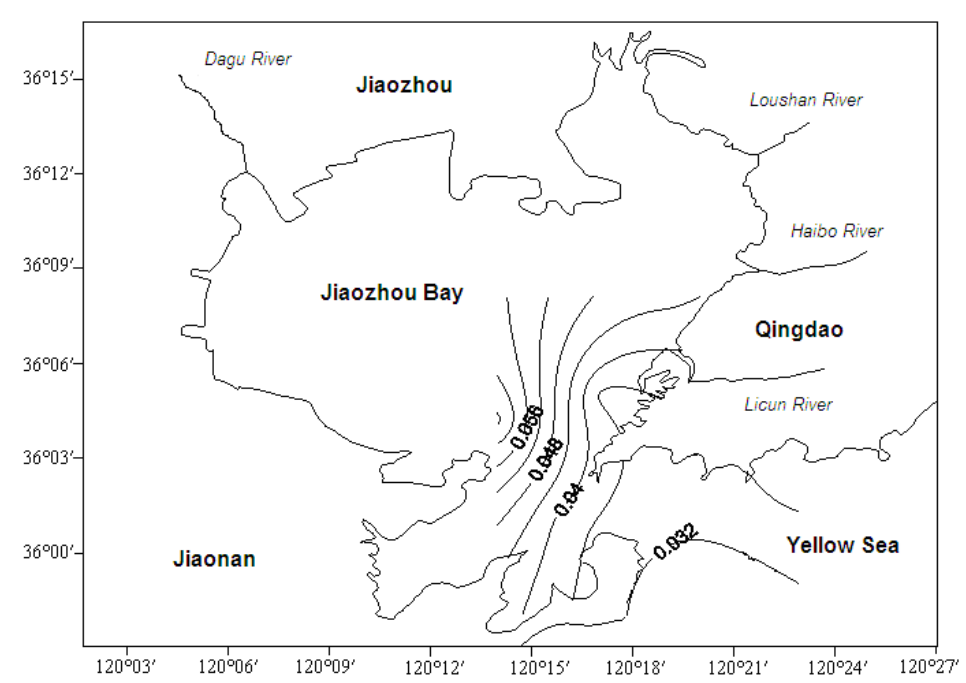

Fig. 5 Horizontal distributions of PHC in bottom waters of Jiaozhou Bay in October 1980

\section{Conclusion}

The contents of PHC in April, August and November in bottom waters in Jiaozhou Bay were 0.036-0.147 mg L $\mathrm{mg}^{-1}, 0.033-0.060 \mathrm{mg} \mathrm{L}^{-1}, 0.068-0.102 \mathrm{mg} \mathrm{L}^{-1}$ and 0.028-0.065 $\mathrm{mg} \mathrm{L}^{-1}$, respectively. By means of the vertical water's effect, PHC contents in Jiaozhou Bay were 0.028-0.147 mg L ${ }^{-1}$, and were belong to Grand II and III. In generally, Jiaozhou Bay waters were slightly polluted by PHC in 1980.

PHC contents in June, September and October were decreasing from the inside of the bay mouth, to the bay mouth, and to the outside of the bay mouth, while in July were decreasing from the outside of the bay mouth to the bay mouth, and to the inside of the bay mouth. By means of vertical water's effect, the contents of the substances could be decreasing continuously from the open waters to the bay, as well as from the bay to the open waters.

\section{Acknowledgement}

This research was sponsored by Doctoral Degree Construction Library of Guizhou Nationalities University, Education Ministry's New Century Excellent Talents Supporting Plan (NCET-12-0659), the China National Natural Science Foundation (31560107), Major Project of Science and Technology of Guizhou Provincial ([2004]6007-01), Guizhou R\&D Program for Social Development ([2014] 3036) and Research Projects of Guizhou Nationalities University ([2014]02), Research Projects of Guizhou Province Ministry of Education (KY [2014] 266), Research Projects of Guizhou Province Ministry of Science and Technology (LH [2014] 7376).

\section{References}

[1] Yang DF, Zhang YC, Zou J, et al.: Open Journal of Marine Science, vol. 2 (2011), p. 108-112

[2] Dongfang Yang, Peiyan Sun, Chen Chen, Hongyan Bai and Qing Zhou: Coastal Engineering, Vol. 32 (2013), p. 60- 72. (in Chinese)

[3] Yang DF, Sun PY, Ju L, et al.: Proceedings of the 2015 international symposium on computers and informatics, vol, (2015), p. 2647-2654.

[4] Yang DF, Wang FY, Zhu SX, et al.: Proceedings of the 2015 international symposium on computers and informatics, Vol. (2015), p. 2661-2666.

[5] Yang DF, Wu FYm He HZ, et al.: Proceedings of the 2015 international symposium on computers and informatics, Vol. (2015), p. 2647-2654. 
[6] Yang DF, Chen Y, Gao ZH, et al.: Chinese Journal of OceanoLogy and LimnoLogy, Vol. 23(2005), p. 72-90.

[7] Yang DF, Wang F, Gao ZH, et al. Marine Science, Vol. 28 (2004), p. 71-74. (in Chinese)

[8] China's State Oceanic Administration: The specification for marine monitoring (Ocean Press, Beijiang 1991), p.1-300. (in Chinese)

[9] Yang DF, Miao ZQ, Xu HZ, et al.: Proceedings of the 2015 international symposium on computers and informatics, Vol. 2015, p. 2655-2660.

[10]Yang DF, Miao ZQ, Xu HZ, et al.: Marine Environmental Science, Vol, 32 (2013), p. 373-380. (in Chinese) 